\title{
VICARIOUS LIABILITY AND THE EMPLOYMENT RATIONALE
}

\author{
David Neild*
}

This article argues that the employment relationship should remain the underpinning rationale for vicarious liability. The article draws a distinction between cases where liability is imposed because the defendant is an employer, and those where liability is based on agency. Other non-employment vicarious liability cases are distinguished using liability for breach of non-delegable duties. The article also considers English cases where vicarious liability has been extended to relationships with similar characteristics to employment, and argues that this approach should be preferred to the New Zealand Court of Appeal's approach in $\mathrm{S} v$ Attorney-General. At the end of the article there is a discussion of the relationship between exemplary damages and vicarious liability. It is argued that, although exemplary damages may be inappropriate in vicarious liability cases, they should be available for breach of a non-delegable duty. Such an approach may better explain some of the decided vicarious liability cases.

\section{INTRODUCTION}

Vicarious liability traditionally arises where an employee commits a tort within the scope of his or her employment. For example, an employer may be liable vicariously for a truckdriver in its employ who negligently drives into another motorist while delivering merchandise for the employer. The development of vicarious liability reflects the fact that the employer is more likely to be able to bear the cost of the accident than the wrongdoer and that, as the employer derives some advantage from the employee's activity, it is fair that the risk of that activity should be allocated to the employer. The rationale underpinning vicarious liability is not fault, as in negligence, but the employment contract between the defendant and the wrongdoer.

The employment rationale underpins the two limbs of what was the orthodox vicarious liability test. First, the defendant and the wrongdoer had to be in an employment relationship. Secondly, the wrong had to be within the scope of the employment. In New Zealand, the employment rationale has been discarded, as the doctrine has been extended to situations where there is no employment contract or even a relationship with employment characteristics. In most commonwealth jurisdictions, the second limb has also been stretched, with the test now focused not on whether the wrong is within the scope of the employment, but whether it is "closely connected" to the work. 
This article argues that those cases that go beyond the employment rationale should be distinguished using the breach of non-delegable duty action. This is important for two reasons. First, the employment rationale informs the two limbs of the test as well as supplying the reason for imposing liability on a third party. There has been a trend in recent vicarious liability cases towards a flexible, policy-based approach, at the expense of identifying a single underpinning rationale or associated test. This does not help practitioners in applying the cases to the facts presented by their clients. It is argued that it is possible to develop a coherent, structured approach for vicarious liability that would still generate the results in the decided cases.

Secondly, as the courts have gone beyond the employment rationale, the distinction between vicarious and direct liability has become blurred. In a number of the leading cases, the courts have focused on the relationship between the defendant and the plaintiff, rather than that between the defendant and the wrongdoer. This undermines an important characteristic of vicarious liability, that it is strict. If vicarious liability is imposed because the defendant's own duties to the plaintiff are breached, the doctrine arguably becomes fault-based, like direct liability in negligence. This has implications for the availability of exemplary damages for vicarious liability, which are discussed at the end of the article.

\section{S V ATTORNEY-GENERAL AND THE FIRST LIMB OF THE VICARIOUS LIABILITY TEST}

The first limb of vicarious liability was traditionally that the defendant was an employer of the wrongdoer. The employment relationship was established if the defendant was able not only to tell the wrongdoer what to do, but how to do it (the control test). ${ }^{1}$ The ability to control the wrongdoer is part of the rationale for imposing liability on the employer even though it is not at fault.

It is the focus on the defendant's relationship with the wrongdoer, rather than with the victim, which distinguishes vicarious from direct liability. The assertion that vicarious liability is strict is legal shorthand for the rule that the defendant's liability is triggered by a relationship with the wrongdoer, not, as in negligence, a relationship of proximity with the victim.

In New Zealand, however, that distinction has been eroded. The leading case is $S v$ AttorneyGeneral, in which the Court of Appeal unanimously imposed vicarious liability on the Crown for the torts of foster parents, although there was no employment relationship and no remuneration. ${ }^{2}$

* Staff solicitor, Gascoigne Wicks, LLM graduate and past volunteer student editor for the law journal. This article is based on a chapter in my master's thesis, submitted as part of the Victoria University of Wellington LLM degree, "Vindicatory Damages in the Child Welfare Context". Many thanks to my two sterling supervisors, Professors Bill Atkin and Geoff McLay, and to Danica McGovern, who read far more drafts on vicarious liability than is sensible. Thanks also to the anonymous reviewer, whose comments were very helpful.

1 Yewens $v$ Noakes (1880) 6 QBD 530 at 532.

2 S v Attorney-General [2003] 3 NZLR 450 (CA) at [64]. 
This decision stretched vicarious liability to relationships outside employment, although the judges differed in their reasoning.

The majority held that foster parents were agents of the Crown and that this established vicarious liability in the same way as an employment relationship. Tipping $\mathbf{J}$, in the minority, preferred to see foster parents as a sui generis class for which the defendants could be held liable. ${ }^{3}$ All the judges, however, accepted implicitly that agency was part of vicarious liability and that vicarious liability could be stretched by analogy with agency or by extending agency itself. The conflation of agency and vicarious liability has been criticised by English academic, Giliker, who emphasises that agency is a primary liability while vicarious liability is secondary. ${ }^{4}$

This criticism puts a lot of weight on the distinction between primary and secondary liability, weight it is not obvious this distinction can bear. In practice, using "vicarious liability" as an umbrella term for both employment and agency based liability should not cause major problems, except for possible confusion in terminology. The distinction between primary and secondary liability can too easily distract attention from the real distinction, that is, the distinction between liability based on an employment relationship and liability based on an agency relationship.

The more pressing problem with the approach in $S v$ Attorney-General is that by treating agency and employment liability as subsets of a wider vicarious liability, the Court introduced a blurry extension of the doctrine which is not based on the two types of relationship previously recognised (employment and agency).

\section{A Agency and Vicarious Liability}

Liability for an agent's torts is usually based on scope of authority, which is similar to, but not the same as, scope of employment. In the New Zealand Supreme Court case Dollars and Sense, ${ }^{5}$ for example, a finance company agreed to lend money on the basis that the debtor, Rodney, obtained and registered a mortgage against his parents' house. Rodney forged his mother's signature and the Court held that his fraud could be attributed to the company based on agency principles: ${ }^{6}$

... Rodney was entrusted with the task, on behalf of D \& S, of obtaining the signatures. He was D \& S's agent for that purpose. D \& S implicitly authorised him to represent it in its dealings with his parents concerning their signature of the documents.

3 At [102].

4 Paula Giliker Vicarious Liability in Tort: A Comparative Perspective (Cambridge University Press, Cambridge, 2010). See also Robert Stevens "Why do agents 'drop out'?" [2005] LMCLQ 101 and PS Atiyah Vicarious Liability in the Law of Torts (Butterworths, London, 1967) at 99.

$5 \quad$ Dollars and Sense Finance Ltd v Nathan [2008] NZSC 20, [2008] 2 NZLR 557.

6 At [27]. 
This case is sometimes cited as authority for the rule that principals can be vicariously liable for their agents. ${ }^{7}$ The word vicarious in this context can be confusing, as the rationales for imposing liability for agency and for vicarious liability are different. Liability in Dollars and Sense was based on the fact that the principal authorised Rodney to represent it. While representing Dollars \& Sense and cloaked with its authority, Rodney forged his mother's signature. While the action was fraudulent, it was still a way of performing the task he was entrusted with. In contrast, vicarious liability is based not on authority or representation, but on an employment relationship and is in part justified by the policy that the employee's work is integrated into the employer's business. ${ }^{8}$ Therefore, it is important that the tort is within the scope of employment. Child abuse, of course, can never be within the scope of any employment arrangement.

\section{B Non-Delegable Duties}

The conflation of agency and vicarious liability in $S v$ Attorney-General is not justified by the result, which could have been achieved by recognising that the Crown has a non-delegable duty to take care of the children placed in its care. This is consistent with the reasoning (but not the ratio) in $S$, which focused on the relationship of the employer and victim, rather than that between the employer and the wrongdoer. The majority observed: ${ }^{9}$

The Superintendent had a duty imposed upon him by statute to take care of the children. He was obliged to fulfil that duty by placing them in suitable private homes where there was supposed to be adherence to practices in accordance with a Departmental manual and continued Departmental monitoring. The Department had a right of inspection and a right to remove any child at any time. The children were said, in the words of the long title to the Child Welfare Act, to be "specially under the protection of the State". That protection cannot have been intended to diminish when a fostering arrangement was made.

Non-delegable duties are typically used to impose liability on defendants for the wrongs of independent contractors because vicarious liability is traditionally only available for the wrongs of employees. ${ }^{10}$ However, non-delegable duties should not be seen as a gap-filler designed to prevent

7 See Stephen Todd The Law of Torts in New Zealand (6th ed, 2013, Thomson Reuters, Wellington) at 1182. Compare Clerk \& Lindsell on Torts (20th ed, 2010, Sweet \& Maxwell, London) at [6-79].

8 Beuermann has argued that agency and employment based liability can be distinguished by the different risks they respond to: "Dissociating the Two Forms of So-Called 'Vicarious Liability'" in Stephen GA Pitel, Jason W Neyers and Erika Chamberlain (ed) Tort Law: Challenging Orthodoxy (Hart Publishing, Oxford, 2013) 463.

9 At [68] (original emphasis).

10 For discussion of non-delegable duties see generally Clerk \& Lindsell on Torts (20th ed, 2010, Sweet \& Maxwell, London) at [6-57]. See also the extensive discussion of third party liability in Robert Stevens Torts and Rights (Oxford University Press, Oxford, 2007). The leading English case is now Woodland v Essex County Council [2013] UKSC 66, in which Lord Sumption gave a useful summary of the case law and the main features necessary before a non-delegable duty can be established. 
defendants escaping liability by contracting out; rather, they are distinct from vicarious liability because they are based on the relationship between the defendant and plaintiff, not that between defendant and wrongdoer.

The leading case in New Zealand on non-delegable duties is Cashfield House Ltd, in which the defendant landlord engaged an independent contractor to demolish part of its premises in order to refurbish the mezzanine floor. ${ }^{11}$ During the demolition work the automatic sprinkler system in the roof fell and ruptured, flooding the ground floor, which was tenanted by the plaintiff. In holding that the landlord was not liable for the contractor's negligence, Tipping J, then in the High Court, confirmed that vicarious liability could never be imposed on a principal for an independent contractor's wrong. He observed, however, that Cashfield would have been liable if it had been negligent in selecting the demolition company (direct negligence) or if it had breached nondelegable duties to the tenant: "the land owner may well be liable because a primary non-delegable duty has been broken: the principal can delegate the task but not the responsibility for its performance". ${ }^{12}$

The Canadian Supreme Court case Lewi $^{13}$ is a useful example of how a non-delegable duty can be derived from a statutory duty like the one in $S$. The Ministry of Transportation and Highways engaged a contractor to remove the rocks from a cliff bordering a highway that they were responsible for repairing. The work was done negligently and one of the remaining rocks fell and killed a passing motorist. Because the work was done by contractors, not employees, the Ministry was not vicariously liable.

The Court held that the Ministry had a non-delegable duty: once it had decided to do the repair work on the cliff, it was liable for any negligence, regardless of whether the work was done by an employee or an independent contractor. The Ministry derived its powers to repair the road from statute and the non-delegable duty arose from the statutory framework. ${ }^{14}$ The rationale underpinning the imposition of non-delegable duties overlaps with the rationale for vicarious liability. For example, in both doctrines, the wrongdoer can often be described as acting on behalf of the defendant, which is also true of agency. However, in vicarious liability the focus is on the

11 Cashfield House Ltd v David \& Heather Sinclair Ltd [1995] 1 NZLR 452 (HC).

12 At 464.

13 Lewis (Guardian ad litem of) v British Columbia [1997] 3 SCR 1145.

14 At [26]. The relevant duty was in the Ministry of Transportation and Highways Act RSBC 1979 c 280, s 45:

The minister shall direct the construction, maintenance and repair of all government buildings, highways and public works in progress, or constructed or maintained at the expense of the Province, and which are under his control. 
relationship between the defendant and the wrongdoer, while liability for breach of non-delegable duties is triggered by the relationship between the defendant and the plaintiff. ${ }^{15}$

In $S v$ Attorney-General, the Court's reasoning emphasised the relationship between the Crown and the children of whom it was meant to take care, not the relationship between the Crown and the wrongdoers. As the Court observed, quoting the relevant statute, the children were "specially under the protection of the state" and the state can therefore be described as having a non-delegable duty to protect them. ${ }^{16}$ This reasoning is more appropriate in the context of non-delegable duties, not vicarious liability.

By imposing liability even though there was no employment relationship, the Court in $S$ removed the rationale that originally underpinned the doctrine, making it much harder to apply. Even if the term "vicarious liability" is used as an umbrella term for third party liability generally, each sub-category needs to be kept distinct so that the relevant inquiry is identified. Once the various doctrines are separated, the correct question emerges: is there a relationship of employment, or of agency, or did the defendant have a non-delegable duty to the victim?

\section{The English Approach: Using the Characteristics of the Employment Relationship}

Although the focus of vicarious liability should remain on the employment relationship, it may be necessary to extend the doctrine where there is no employment contract but the relationship has many of the essential characteristics of employment.

In the English Court of Appeal case Portsmouth, the plaintiff alleged that she had been abused while in a children's home run by nuns of the defendant church trust and that she was sexually abused by the priest of that parish, Father Baldwin. ${ }^{17}$ The first issue was whether the Trust and

15 At [53].

$16 S v$ Attorney-General concerned the Child Welfare Act 1925, the long title of which was:

AN ACT to make Better Provision with respect to the Maintenance, Care, and Control of Children who are specially under the Protection of the State; and to provide generally for the Protection and Training of Indigent, Neglected, or Delinquent Children.

The Court emphasised a number of the Crown's powers under the statute, including s 12:

12 Director-General may agree with parent or other authorised person to assume control of child

(1) The Director-General may, on application in that behalf made by either parent of any child or by its guardian, or by any person having for the time being the custody or control of the child, assume control of that child for such period and on such terms as to cost of maintenance and otherwise as may be agreed on by the parties.

17 JGE v The Trustees of the Portsmouth Roman Catholic Diocesan Trust [2012] EWCA Civ 938. 
Father Baldwin were in a relationship sufficient to establish vicarious liability. It was accepted that there was no employment relationship because the parties did not intend to be legally bound by their agreement that Father Baldwin take up responsibilities in that parish and relied instead on canon law. ${ }^{18}$

Ward LJ held that a defendant could be liable for another's wrong if they were in a relationship akin to employment, which he defined as follows: ${ }^{19}$

To distil it to a single sentence I would say that an employee is one who is paid a wage or salary to work

under some, if only slight, control of his employer in his employer's business for his employer's

business. The independent contractor works in and for his own business at his risk of profit or loss.

Applying the first part of this test, May LJ emphasised that the bishop was required to see to it that "due provision" was made for the priests, which he held was very like being paid a wage. Residing in the parochial house close to the church was also like "the employee making use of the employer's tools of trade." 20 On the control part of the test, May LJ held that the priest was accountable to his bishop (the head of the Diocese), who could direct him on how to do his job (and especially how not to do it). ${ }^{21}$ Finally, the role of the priest was central to the aims of the "business", spreading the word of God, and was fully integrated into the organisational structure of the Church's enterprise. $^{22}$

The other judge in the majority, Davis LJ, adopted a test which also focused on control and the aims of the business. ${ }^{23}$ Davis LJ also considered the situation where a priest working in the bishop's own office receives a complaint that a parish priest is abusing children, but does not tell the bishop. On the traditional approach, there would be no vicarious liability because the priests are not employees of the bishop.

This hypothetical situation is useful because it highlights the importance of control. The bishop could be expected to have a high degree of control over the priests on his staff. However, in Portsmouth the Bishop was only required to visit his parish priests at least once every five years and was restricted in his ability to remove priests or to move them to other parishes. Any weakness in the decision in Portsmouth probably lies not in the test adopted, but in the application. As Tomlinson LJ in the minority pointed out, "The [trial] judge's findings ... as to lack of control
18 At [30].
19 At [70]
20 At [79].
21 At [76].
22 At [77]-[78].
23 At [123]. 
exercised by a diocesan bishop over the priests in his diocese set this case apart from any other hitherto decided". 24

However, even if the application to the particular facts can be criticised, the majority judgments are useful for the way they attempt to distil the essence of the employment relationship. Control, wages, integration into the employer's business organisation and the role of the employee in furthering the aims of the business are useful criteria for identifying a relationship akin to employment. Applying them to Davis LJ's hypothetical, the bishop is likely to be vicariously liable for the wrongs of the priests on his personal staff, if not the wrongs of the more independent parish priests.

The Portsmouth approach was approved by the United Kingdom Supreme Court in another sexual abuse case against the Catholic church, The Catholic Child Welfare Society $v$ The Institute of the Brothers of the Christian Schools. ${ }^{25}$ The Institute is legally an unincorporated society, whose members teach in schools under its management. Like the defendants in Portsmouth, the brothers do not have employment agreements, but they undertake to "go wherever I may be sent and to do whatever I may be assigned by the [Institute] or its superior." 26

Lord Phillips, who gave the only judgment, focused, like Ward LJ, on the characteristics of the relationship between the defendant and the wrongdoer. He observed that the first limb of the twolimb vicarious liability test was the identification of an employment relationship and identified five policy factors that justified imposing liability on employers. ${ }^{27}$ The first is often described as the deep pockets rationale: the employer is more likely than the employee to be insured and to be able to compensate the plaintiff. ${ }^{28}$

The next three rationales focus on the fact that the tort was committed as part of the defendant's business. These rationales are likely to be also relevant where liability is for non-delegable duties or agency. First, the tort will have been committed "on behalf of the employer". ${ }^{29}$ Secondly, the employee's activity "is likely to be part of the business activity of the employer". ${ }^{30}$ Thirdly, the employer's business creates the risk of the tort being committed. ${ }^{31}$ This rationale has been behind

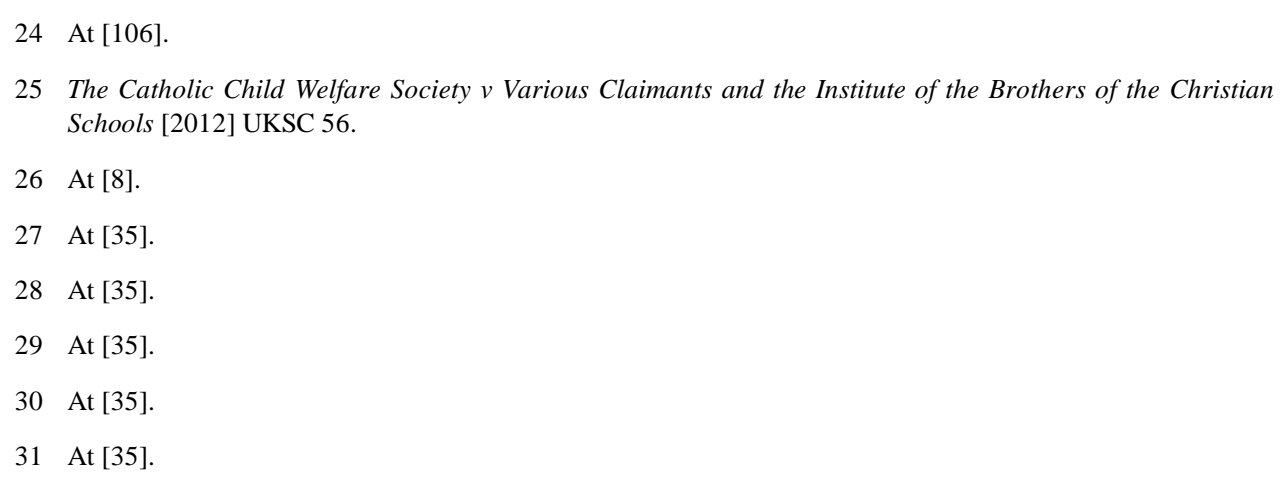


much of the development of the scope of employment limb, as discussed is the second part of this article. It is often referred to as the enterprise risk rationale.

The final rationale identified by Lord Phillips is the traditional core of the first limb of the test, that is, the employee is subject to the control of the employer. ${ }^{32}$ While control was emphasised by both Lord Phillips and Ward LJ in Portsmouth, Lord Phillips acknowledged that "[t]oday it is not realistic to look for a right to direct how an employee should perform his duties as a necessary element in the relationship between employer and employee. ${ }^{33}$ It will usually be enough now if the employer can direct the employee what to do. ${ }^{34}$

Lord Phillips emphasised the overlap between the policy underpinning the doctrine and the criteria for liability, observing that, while policy and criteria are not the same, "[o]ne cannot ... consider the one without the other". ${ }^{35}$ His five rationales for liability focus on the employment relationship and his discussion of the facts highlights those factors that most characterise the relationship between the defendant and wrongdoer as akin to employment. In this way, the employment relationship provides the underpinning rationale and the criteria for the first limb of the vicarious liability test.

Although the brothers in the Institute were bound together not by contract but by vows and were paid no remuneration, Lord Phillips identified four elements of the relationship which made it akin to employment. First, the Institute was hierarchical and "conducted its activities as if it were a corporate body." 36 The second and fourth elements emphasised control: the brothers undertook to teach the plaintiffs because they were "directed" to do so by the Institute, and the behaviour of the brothers was dictated by the Institute's rules. ${ }^{37}$ The third element identified by Lord Phillips reflects the enterprise risk rationale: "[t]he teaching activity undertaken by the brothers was in furtherance of the objective, or mission, of the Institute." 38 Overall, Lord Phillips observed that the facts in The Institute presented an even stronger case for imposing vicarious liability than those in Portsmouth. ${ }^{39}$
32 At [35].
33 At [36] (emphasis added).
34 At [36].
35 At [34].
36 At [56].
37 At [56].
38 At [56].
39 At [55]. 


\section{The English and New Zealand Tests Compared}

The relationship in $S$ between foster parents and the Crown would probably fail the test in Portsmouth. Although the Crown possibly visits foster parents more often than the Bishop visits his parish priests (at least once every five years), there is nothing resembling a wage in the relationship between the Crown and foster parents. Whatever the results of applying the Portsmouth test to the facts in $S v$ Attorney-General, however, the English test should be preferred for three reasons. First, it is far easier to apply. Secondly, it retains the focus of vicarious liability firmly on the employment relationship. Thirdly, there is an alternative, more principled way of holding the Crown accountable for the wrongs of foster parents through non-delegable duties.

The Portsmouth test includes clear criteria, which stem from an underpinning rationale that employers should be liable for the wrongs of their employees and that, therefore, judges should look for the essence of an employment relationship if there is no legal employment contract. ${ }^{40}$ The test in $S v$ Attorney-General, in contrast, stretches agency concepts, based on a conflation of the agency and vicarious liability tests. The Court imposed vicarious liability on the Crown for reasons that were more to do with the duties the Crown owes children entrusted to its care than the relationship between the defendant and wrongdoer, blurring the distinction between no-fault vicarious liability and direct negligence.

\section{COURSE OF EMPLOYMENT}

The next part of this article is a discussion of the way the distinction between breach of a nondelegable duty and vicarious liability clarifies issues concerning the second part of the vicarious liability test. The second limb, often called the "Salmond test" after the torts textbook, is as follows: ${ }^{41}$

A master is not responsible for a wrongful act done by his servant unless it is done in the course of his employment. It is deemed to be so done if it is either (a) a wrongful act authorised by the master, or (b) a wrongful and unauthorised mode of doing some act authorised by the master.

The course of employment test caused problems in child abuse cases because it is difficult to describe deliberate abuse as within the course of employment or as an unauthorised mode of doing an authorised act. ${ }^{42}$

\section{$A$ Bazley and Jacobi}

The first episode in the child care series was the Canadian case, Bazley. The wrongdoer, Curry, had been employed by the defendant non-profit organisation in its residential care facilities for

40 For a similar rationale see Jason Neyers "A Theory of Vicarious Liability" (2005) 43 Alberta LR 1.

41 John W Salmond The Law of Torts (1 st ed, Stevens and Haynes, London, 1907) at 83 (original emphasis).

42 Lister v Hesley Hall Ltd [2001] UKHL 22, [2002] 1 AC 215 at [68]. 
children between the ages of six and twelve. He had been required to interact with the plaintiff as a parent would do, which included bathing and tucking in at bedtime. Like most child abuse victims, Bazley found that the abuser was not worth suing and turned to the employer instead. However, Bazley faced the obvious difficulty of establishing vicarious liability against his abuser's employer as child abuse could not possibly be described as within the scope of the employment contract.

The Canadian Supreme Court in Bazley got around this problem by relying on the 1912 case Lloyd for the rule that employers could be liable for their employee's theft of property. ${ }^{43}$ The Supreme Court assumed that Lloyd was decided upon vicarious liability and concluded that it would be wrong to hold employers liable for their employee's thefts but not their abuse of children: "[s]urely a distinction is not to be drawn attributing a higher standard to the way society looks after its jewellery than its children." ${ }^{44}$ However, as discussed below, it is not clear that Lloyd was based on vicarious liability and it is arguable that Bazley could have been decided using non-delegable duties.

The Supreme Court handed down a single judgment in Bazley, delivered by McLachlin J, which purported to follow the Salmond test. However, it effectively overhauled the test by reformulating it as whether there was a close connection between the opportunity that the employer created and the wrong the employee committed (the enterprise risk test). ${ }^{45}$ McLachlin $\mathrm{J}$ held that the defendant in Bazley had materially increased the risk of child abuse by placing Curry in a position of parent-like responsibility with vulnerable children in situations of intimacy. ${ }^{46}$

The Supreme Court released a second decision on the same day as Bazley in which it decided by a majority of four to three not to impose vicarious liability. In Jacobi v Griffiths the Vernon Boys' and Girls' Club was, unlike the Foundation in Bazley, a recreational rather than a residential facility. ${ }^{47}$ Children attended for sports and other activities after school and on Saturdays. There were occasional outings. The Club employed Griffiths as its Programme Director, whose task it was to organise the activities and outings. The plaintiffs, Joy and Randy, were siblings, and attended the Club to play hockey and participate in gymnastics. They were both abused by Griffiths, who pleaded guilty to criminal charges before the civil proceedings, although all of the abuse took place away from school premises and (except for one incident) outside school hours.

43 Lloyd v Grace, Smith \& Co [1912] AC 716 (HL).

44 Bazley v Canada [1999] 2 SCR 534 at [24].

45 At [41].

46 At [58].

47 Jacobiv Griffiths [1999] 2 SCR 570. 
It is difficult to distinguish Bazley and Jacobi based on the enterprise risk test. In both cases, it is hard to see how the provision of child care facilities for children like Bazley increased the risk of child abuse, as Neyers and David Stevens have pointed out: ${ }^{48}$

... it does not make sense to say that the existence of any particular institution increases the risk of paedophilia ... since the alternative to the institution is the street. Surely the children are more vulnerable and the paedophile more empowered if they are left on the street.

Bazley is based on an assumption that vicarious liability can be imposed for an employee's intentional wrongs, applying cases such as Lloyd. However, as suggested in the next section, Lloyd could be analysed as an example of liability for breach of a non-delegable duty. Such an approach would also explain the difference in result between Bazley and Jacobi.

\section{B Lloyd and Non-Delegable Duties}

In Lloyd, a firm of solicitors was held liable for the dishonesty of their clerk, who had persuaded a client to transfer property to him, which he used to his own advantage. The modern importance of Lloyd is its value as precedent for the rule that employers can be liable for the intentional torts of their employees. However, controversy surrounds the argument that this case is an example of vicarious liability, as opposed to agency or liability for breach of non-delegable duty.

Salmond himself appears to have viewed the case as changing the rules of vicarious liability: ${ }^{49}$

It was long supposed that where the fraud or other wilful wrongdoing of the servant was committed for his own benefit and not on his master's behalf, his master was not responsible. It has now been decided by the House of Lords, however, in Lloyd v Grace Smith \& Co that this is not the case ...

48 Jason W Neyers and David Stevens "Vicarious Liability in the Charity Sector: an Examination of Bazley v Curry and Re Christian Brothers of Ireland in Canada" (2005) 42 Can Bus LJ 371, at 402, arguing that there should have been no liability in Bazley because it discourages charities, without which the plaintiffs would have been in a worse position. For an argument that there should have been liability in both Bazley and Jacobi see Sheila McIntyre "Guardians of Privilege: The Resistance of the Supreme Court of Canada to Institutional Liability for Child Sexual Abuse" in Sanda Rodgers, Rakhi Ruparelia and Louise BélangerHardy (eds) Critical Torts (LexisNexis, Markham, 2009).

49 John W Salmond The Law of Torts (4th ed, Stevens and Haynes, London, 1916) at 99, compare the third edition (1912) at 93, which was published before Lloyd. However, see the note by Frederick Pollock on the case at (1913) 29 LQR 10, which emphasises the agency aspects and the relationship between the plaintiff and defendant. See also Pettersson v Royal Oak Hotel Ltd [1948] NZLR 136 (CA) where a customer threw a glass at a bar attendant and the attendant threw part of it back at him, negligently injuring another customer (the plaintiff). The Court of Appeal held that the employer was vicariously liable, although the attendant was motivated by personal resentment. Lloyd was cited as authority for this in the oral argument. However, it is not clear that this case would be decided the same way today: Stephen Todd (ed) The Law of Torts in New Zealand (5th ed, Brookers, Wellington, 2009) at 1048. 
In a 1964 case, Lord Denning appears to have treated the case as one of agency. ${ }^{50}$ However, Bowstead and Reynolds on Agency seems to treat the case as an example of vicarious liability, but acknowledges that "in common speech" the clerk might be "more appropriately described as [an] agent". 51

Modern torts scholars have argued that Lloyd should be seen as an example of liability for breach of non-delegable duty. ${ }^{52}$ On this interpretation, liability would be based on the interaction between the solicitor and the client, rather than any employment or agency relationship between the solicitor and the clerk.

\section{Bazley and Jacobi Explained with Non-Delegable Duties}

While the risk enterprise test cannot explain cases such as Bazley because it is not obvious that the risk to children is increased when charities provide residential care facilities for emotionally troubled children, the result may be more readily explained with non-delegable duties. The defendant in Bazley arguably assumed responsibility for the care of the plaintiff; although it can delegate that care to an employee, it cannot delegate the responsibility.

As Stevens has argued, the non-delegable explanation of Lloyd also explains the result in Jacobi: ${ }^{53}$

... the Supreme Court of Canada in Bazley v Curry reached the right result for the wrong reasons ... it stretches credulity to suggest that running a non-profit residential care home for emotionally troubled children increases the risk of children being abused ... if the claims in Bazley and Jacobi had been seen as based upon voluntarily assumed duties that care would be taken of the children, the difference in result is readily explicable. The scope of the duty undertaken must be ascertained. What was the club in Jacobi undertaking to do? There was an undertaking that care would be taken of the children at the club, but they are not assuming a duty to care for the child once he or she goes home.

\section{$D$ Lister and Assumption of Responsibility}

Stevens' argument is especially compelling when applied to the House of Lords case Lister, in which the judges applied the "close connection" test from Bazley, but explicitly introduced ideas to

50 Rooke v Viscount Chelmsford [1965] 1 QB 248 (CA), at 261.

51 Peter Watts and FMB Reynolds Bowstead and Reynolds on Agency (19th ed, Sweet \& Maxwell, London, 1010) at 487.

52 See Neyers and Stevens, above n 48, at 394; John Murphy "Judicial Foundations of Common Law NonDelegable Duties" in Jason W Neyers, Erika Chamberlain and Stephen GA Pitel (eds) Emerging Issues in Tort (Hart Publishing, Oxford, 2007) 369 at 376.

53 Robert Stevens "Non-delegable Duties and Vicarious Liability" in Jason W Neyers, Erika Chamberlain and Stephen GA Pitel (eds) Emerging Issues in Tort (Hart Publishing, Oxford, 2007) at 361-362; emphasis in original. 
do with assumption of responsibility. In Lister, the warden at a boarding school for boys had abused one of the children in his care. Like the home in Bazley, the facilities were residential and it was meant to feel like a home rather than an extension of school. The House of Lords adopted what it saw as the ratio of Bazley and Jacobi, assessing the connection between the tort and the authorised action. The judges argued that this was consistent with the real Salmond test, by returning to the first edition of Salmond for the following passage: ${ }^{54}$

... a master ... is liable even for acts which he has not authorised, provided they are so connected with

acts which he has authorised, that they may rightly be regarded as modes ... of doing them.

Lord Steyn observed, "Salmond's explanation is the germ of the close connection test adumbrated by the Canadian Supreme Court in Bazley ... and Jacobi ..." 55

Most of the Law Lords in Lister also discussed the duty that the defendants owed to the plaintiffs. Lord Steyn observed that "It becomes possible [under the Lister approach] to consider the question of vicarious liability on the basis that the employer undertook to care for the boys through the services of the warden ..."56 Lord Hobhouse observed that Bazley illustrates a "situation where the employer has assumed a relationship to the plaintiff ..."57

The emphasis on assumption of responsibility and the voluntary undertakings by the defendant is consistent with the non-delegable duty approach advocated by Stevens and Murphy. The focus is on the relationship between the defendant and plaintiff, as in liability for breach of a non-delegable duty, rather than on the relationship between the defendant and wrongdoer. This is also consistent with the reasoning in $S v$ Attorney-General.

\section{E Non-Delegable Duties Applied to White}

In the 2008 New Zealand case White v Attorney-General, Miller J declined to stretch the $S v$ Attorney-General reasoning to abuse by biological parents. ${ }^{58}$ The two plaintiffs were brothers, part of a large family whose father was abusive. Among other things he beat the children for getting

54 Salmond, John W The Law of Torts (1st, Stevens and Haynes, London, 1907) at 83-84, quoted in Lister, above $\mathrm{n} 42$, at [15] (emphasis added).

55 At [15].

56 At [20].

57 At [54] (emphasis added).

58 White v Attorney-General HC Wellington CIV-1999-485-85, CIV-2001-485-864, 28 November 2008; White v Attorney-General [2010] NZCA 139. Leave to appeal was refused by the Supreme Court: $W v$ Attorney-General [2010] NZSC 69, (2010) 19 PRNZ 921. 
caught when stealing on his instructions. The Department of Social Welfare ${ }^{59}$ knew about the family and monitored them, eventually obtaining court-ordered supervision over the boys.

After the children were made state wards by court order, they were returned to their biological parents. Since the children were left in the care of their parents by the Child Welfare Branch ${ }^{60}$ while under supervision, the plaintiffs pleaded (among other things) vicarious liability for the intentional torts of their parents. Miller J observed that: ${ }^{61}$

... they were not appointed in the sense that they were selected by the Director-General from a pool of

available foster parents. Rather, Mrs White was the plaintiffs' mother and there were no viable

alternatives to placing them in her care.

Miller $\mathrm{J}$ applied the quasi-agency test in $S$, asking whether "the plaintiffs or the wider community would consider that Mrs White and Mr Vincent were acting on [the Director-General's] behalf." 62 The question may have been answered differently if Miller $\mathbf{J}$ had focused on whether the Director-General had assumed responsibility for the children's safety, taking into consideration any statutory duties, previous interaction between the plaintiff and defendant and whether and why the defendant relied on the plaintiff. White concerned the same statutory framework as $S v$ AttorneyGeneral. Arguably, when the children became wards, the Crown took on a responsibility to take care of them that could not be delegated to third parties, even to the children's own parents.

\section{VICARIOUS LIABILITY AND EXEMPLARY DAMAGES}

Distinguishing between liability based on relationships akin to employment and liability for breach of non-delegable duties helps in understanding the awkward position of exemplary damages in the context of vicarious liability.

In the Couch litigation, the New Zealand Supreme Court held that exemplary damages were intended only to punish. ${ }^{63}$ Susan Couch sued the Crown for injuries suffered in an attack by William Bell, who was on parole at the time. It was alleged that the Crown was vicariously liable for the

59 Now the Ministry of Social Development.

60 Now Child, Youth and Family.

61 At [373].

62 At [374].

63 Couch v Attorney-General (No 2) (on appeal from Hobson v Attorney-General) [2010] NZSC 27; [2010] 3 NZLR 149. This was the second of two decisions from the Supreme Court; the first is Couch v AttorneyGeneral (on appeal from Hobson v Attorney-General) [2008] NZSC 45, [2008] 3 NZLR 725. For a discussion of Couch and vicarious liability, see Stephen Todd "Vicarious Liability, Personal Liability and Exemplary Damages" in S Degeling and others (eds) Torts in Commercial Law (Thomson Reuters, Sydney, 2011). 
negligence of the parole officer. ${ }^{64}$ Since vicarious liability is strict, Tipping J observed obiter that it would never be appropriate to impose exemplary damages vicariously. While it might be appropriate to force a faultless employer to pay for the loss of a victim who is equally innocent when the real wrongdoer is impecunious, forcing the defendant to pay non-loss based damages is less easily justified: ${ }^{65}$

When one person is acting on behalf of another, the wrong is seen for the purposes of compensation as having been committed both by that person and by the other. But the policy behind awarding compensatory damages against a person on the basis of vicarious liability does not mean that exemplary damages should be similarly awarded. There is no policy basis for punishing someone for the conduct of another unless the first person's conduct itself also qualifies for punishment. People should not be vicariously liable for punishment on account of the conduct of someone else just because that conduct renders them liable to compensate the plaintiff.

If vicarious liability is indeed strict and if exemplary damages are intended to punish, Tipping $\mathrm{J}$ 's argument is compelling. However, as discussed above, in stretching vicarious liability, the courts have increasingly focused on the relationship between the defendant and the plaintiff, blurring the line between vicarious and direct liability. Since exemplary damages are still available in negligence, it may be difficult to exclude them entirely from vicarious liability when it is increasingly difficult to distinguish the latter from negligence. This raises the issue of whether vicarious liability is still strict.

The problem is well illustrated by Blackwater v Plint, in which the Canadian Supreme Court accepted that vicarious liability can imply fault. The plaintiff had been removed from his aboriginal community and placed in a special school run by the Government of Canada and the United Church of Canada, where he had been physically and sexually abused. ${ }^{66}$

The church and the Government were both held vicariously liable for their employee's torts. The issue was whether liability could be apportioned unequally. The trial judge apportioned the damages 75 per cent to the Crown and 25 per cent to the church. The Crown argued that, if vicarious liability was truly no-fault, it was impossible to apportion liability unequally. The Supreme Court was forced to concede that vicarious liability implied some fault and that this justified greater liability on the part of the Crown because the trial judge had found that the Crown was in a better position to

64 The Crown agreed to pay any damages for which its employees were liable, whether it was vicariously liable for those damages or not. See the discussion in Stuart Anderson "'Grave injustice': the insecure foundations of crown liability for torts in New Zealand" (2009) 12 Otago LR 1.

65 At [158].

66 Blackwater v Plint (2005) SCC 58, [2005] 3 SCR 3. 
control the wrongdoer. On whether vicarious liability was no-fault, McLachlin CJ, writing for the Court, observed: ${ }^{67}$

The most compelling view is that while vicarious liability is a no-fault offence in the sense that the employer need not have participated in or even have authorized the employee's particular act of wrongdoing, in another sense it implies fault ... the degree of fault may vary depending on the level of supervision. Parties may be more or less vicariously liable for an offence, depending on their level of supervision and direct contact.

Rather than stretching vicarious liability, however, this case could have been decided using nondelegable duties. The school in which the plaintiff was abused was run by both defendants, the church and the state, but without the state's exercise of its statutory powers, the plaintiff could never have been removed from her aboriginal community and placed in the school. Applying nondelegable duty reasoning, the responsibility that the state was unable to delegate was higher than the church because its statutory powers were more extensive.

If cases like Blackwater are analysed as involving breach of non-delegable duties, the more orthodox cases involving relationships akin to employment can be preserved as a discreet area of strict liability, distinct from direct liability. Exemplary damages will never be appropriate in these cases, as Tipping observed in Couch, ${ }^{68}$ but they may sometimes be available if liability is based on breach of a non-delegable duty, for the same reasons that exemplary damages cannot be excluded from direct negligence.

\section{CONCLUSION}

The distinction between vicarious and direct liability depends on whether the defendant's liability is triggered by its relationship with the plaintiff or the wrongdoer. As that distinction has been gradually eroded through cases such as $S v$ Attorney-General and Lister, vicarious liability has become less strict. However, those cases in which the reasoning has focused most on the defendant's own duties to the plaintiff can be distinguished using breach of non-delegable duties. This preserves the non-fault character of vicarious liability.

The distinction between non-delegable duties and vicarious liability also helps to keep the latter in its proper context, the employment relationship. Developing the doctrine by reference to the characteristics of this type of relationship, as the English Court of Appeal did in Portsmouth, retains the underpinning rationale of vicarious liability and ensures the test is simple to apply. This approach should be preferred to the vague extension of the doctrine in $S v$ Attorney-General by references to agency.

67 At [69].

68 At [158]. 
